\title{
PODOBE O BRANISLAVI SUŠNIK MED SLOVENCI V ARGENTINI: MIGRACIJA, ŽIVLJENJE V PARAGVAJU IN POVEZAVE Z DOMOVINO
}

\author{
Jaka REPIČ
}

COBISS 1.01

\section{IZVLEČEK}

\section{Podobe o Branislavi Sušnik med Slovenci v Argentini:}

Migracija, življenje v Paragvaju in povezave z domovino

Članek predstavlja življenje in raziskovalno delo Branislave Sušnik, ki se je po drugi svetovni vojni najprej izselila v Argentino in nato v Paragvaj, kjer je delovala na raziskovalnih področjih jezikoslovja, antropologije in kulturne zgodovine staroselskih ljudstev. Osredotoča se na analizo njenih migracijskih izkušenj, povezav z domovino, predvsem pa na podobe, ki so se o njej kot izseljenski znanstvenici med Slovenci v Argentini izoblikovale $v$ tisku.

KLJUČNE BESEDE: Branislava Sušnik, slovenska diaspora v Argentini, Paragvaj, izseljenska znanstvenica

\section{ABSTRACT \\ Images of Branislava Sušnik among the Slovenians in Argentina: Migration, Life in Paraguay, and Connections with the Homeland}

The article presents the life and research of Branislava Sušnik, who fled Slovenia after World War II, emigrating first to Argentina and eventually to Paraguay. In Paraguay, she worked in ethnolinguistics, anthropology, and the cultural history of Paraguayan indigenous peoples. The article mainly analyzes her migration experiences, her connections with the homeland, and particularly the images of Branislava Sušnik as a migrant scientist constructed in the publications of the Slovenian diaspora in Argentina. KEYWORDS: Branislava Sušnik, Slovenian diaspora in Argentina, Paraguay, migrant scientist

Dr. etnologije, izredni profesor za kulturno in socialno antropologijo, Filozofska fakulteta Univerze v Ljubljani, Aškerčeva 2, SI-1000 Ljubljana; jaka.repic@ff.uni-lj.si, https://orcid.org/0000-00032009-4369 - Članek je nastal v okviru raziskovalnega programa »Slovenske identitete v evropskem in svetovnem kontekstu« (P6-0187). Raziskovalni program je sofinancirala Javna agencija za raziskovalno dejavnost Republike Slovenije iz državnega proračuna. Prav tako je članek rezultat Ciljnega raziskovalnega projekta »Dr. Branislava Sušnik in njeni sodobniki« (2019-2020), ki ga je na predlog Urada Vlade RS za Slovence v zamejstvu in po svetu sofinancirala Javna agencija za raziskovalno dejavnost Republike Slovenije iz državnega proračuna. 


\section{UVOD}

Branislava Sušnik je po drugi svetovni vojni kot begunka zapustila Slovenijo in se v Paragvaju uveljavila kot raziskovalka in direktorica Etnografskega muzeja Andrés Barbero v Asunciónu. Kot »izseljenska znanstvenica« v domovini dolgo ni bila znana, dobro pa jo je poznala povojna slovenska skupnost v Argentini, z njimi je vsaj na začetku delila podobne življenjske izkušnje. V Argentino se je preselila leta 1947. Po štirih letih se je preselila v Paragvaj, kjer se je do smrti leta 1996 poklicno udejstvovala v etnolingvistiki, antropologiji, muzeologiji, arheologiji ter kulturni in kolonialni zgodovini paragvajskih staroselskih ljudstev.

Članek obravnava migracijske razsežnosti življenja in raziskovanja Branislave Sušnik, tj. družbenopolitični kontekst njene migracije, begunsko izkušnjo, odnos z domovino in s slovensko skupnostjo v Argentini, predvsem pa podobe, kot so se o njej oblikovale v slovenskem tisku v Argentini. O njej je pisalo že nekaj avtorjev, a do zdaj še nihče ni sistematično in kritično obravnaval njenih povezav $\mathrm{s}$ slovensko diasporo v Argentini. Pričujoči članek te povezave in oblikovanje podob o njej obravnava s stališča »izseljenske znanstvenice« in »raziskovalke indijanskih plemen« (Debeljak 1976a). Podobe o njej so, vsaj kjer zadeva protikomunistično držo, razloge za begunstvo, (ne)vpetost v izseljensko družbeno okolje in zunanje interpretacije intimnih povezav $z$ domovino, vpete $v$ diasporični ideološki okvir.

Branislavo Sušnik članek umešča v večplastne migracijske kontekste. V prvem delu na kratko predstavi njeno biografijo, predvsem razloge, ki so pripeljali do povojne emigracije. Nadalje obravnava begunsko izkušnjo, selitvi v Argentino in Paragvaj, kjer je našla raziskovalno svobodo in se strokovno uveljavila. Kljub odmiku od slovenske skupnosti v Argentini je ohranjala stike s posamezniki, v njihovem tisku objavila nekaj znanstvenih del in se v zavest diaspore zasidrala kot izseljenska znanstvenica. Slovenska diaspora si je Branislavo Sušnik prisvojila, v njej oblikovane podobe pa še vedno zaznamujejo splošno poznavanje njenega življenja in raziskovalnega dela v Paragvaju ter s tem sooblikujejo interpretativni model, $v$ katerem se vzpostavlja sodobno razumevanje njenega življenja, če ne celo sodobna mitologija o njeni osebnosti.

Metodološko članek temelji na analizi znanstvenih del Branislave Sušnik, ki so izšla v slovenskem tisku v Argentini, objavljenih intervjujih ter drugih člankih o njej. Temeljno gradivo analize je slovenski tisk v Argentini, predvsem letni zborniki časopisa Meddobje in Zborniki Svobodne Slovenije, časopis Svobodna Slovenija in druge pomembnejše publikacije, kot so Vrednote, Misijonski zbornik, Zgodovinski zbornik in Katoliški misijoni. Analiza omenjenih publikacij razkriva, da je bila Branislava Sušnik občasno vpeta v slovensko skupnost (npr. Debeljak 1958; 1976a; Mizerit 2018), predvsem v petdesetih letih 20. stoletja tudi zaradi objav znanstvenih del ali predavanj (Sušnik 1953; 1954a; 1954b; 1959; 2018). Naštete publikacije članek obravnava s kritično distanco, po eni strani so temeljno ideološko orodje diaspore, po drugi strani pa bogat vir, ki so ga upoštevali drugi avtorji, ko so pisali o Branislavi Sušnik (npr. Telban 1993; Mislej 1998; 2007; Rijavec 2000; Saksida 2012; Peris 2014). 


\section{BRANISLAVA SUŠNIK OD BEGUNSTVA DO RAZISKOVANJA STAROSELCEV V JUŽNI AMERIKI}

Branislava Sušnik se je rodila 28. marca 1920 v Medvodah. Že v mladosti se je njena družina preselila v Polje pri Ljubljani, kjer je oče Jože Sušnik delal kot poveljnik žandarmerijske postaje. Obiskovala je drugo državno realno gimnazijo Poljane $v$ Ljubljani, kjer je kot profesor poučeval tudi etnolog Niko Kuret. Kuret je že v gimnaziji opazil njen dar za zgodovino in jezike ter jo navdušil za zgodovinske in etnološke teme (Mislej 1998: 275). Po gimnaziji se je leta 1937 vpisala na Filozofsko fakulteto v Ljubljani, kjer je študirala zgodovino in prazgodovino. Študij je leta 1942 zaključila z diplomskim delom Evropa in azijska prazgodovina in bosansko-turška etnologija (Rijavec 2000: 15). Obenem je obiskovala predavanja na Teološki fakulteti v Ljubljani, kjer je nanjo močno vplival Ehrlich Lambert, zagovornik dunajske kulturnozgodovinske šole in difuzionistične teorije kulturnih krogov. Leta 1942 naj bi na Dunaju doktorirala pri Wilhelmu Schmidtu, a je to precej dvomljivo. ' Leta 1943 je obiskovala predavanja na Biblijskem inštitutu v Vatikanu.

Med izobraževanjem se je usmerjala $v$ azijske jezike in kulture, a jo je pozneje življenjska pot zanesla v Južno Ameriko. Tine Debeljak, eden glavnih literarnih ustvarjalcev $v$ slovenski skupnosti v Argentini, je njeno življenjsko pot razložil skozi ideološki okvir diaspore in z globalnimi političnimi spremembami ter s širitvijo komunizma po drugi svetovni vojni: »Vzhod, za katerega se je $z$ velikim študijem pripravljala v Rimu, se je zaprl, odprl pa Zahod. Namesto med azijske Indijce in Kitajce, kamor je bila namenjena in si pripravljala jezikovno znanje, jo je usoda pripeljala med južnoameriške Indijance v Paragvaj.» (Debeljak 1976a: 300)

Razlogi za njeno migracijo po drugi svetovni vojni so bili politični, izhajali pa so celo iz osebne travme. Že na začetku vojne je odporniško gibanje ubilo njenega očeta: »Njen oče, Jože Sušnik, vodja žandarmerijske postaje v Devici Mariji v Polju, je padel med prvimi žrtvami komunističnih morilcev. Že 18. avgusta 1941 ga je, vpričo hčerke, ustrelil Albin Grajzer. Po Grajzerju [...] se še danes imenuje cesta v Vevčah.« (Mizerit 2018: 3)

Življenjska pot Branislave Sušnik je bila med vojno neposredno vpeta v ideološki boj, zato naj bi vse življenje nasprotovala komunizmu in drugim avtoritarnim režimom (Peris 2014: 21). Debeljak je celo zapisal, da je njen oče "padel kot prva žrtev revolucije v Sloveniji« (Debeljak 1976a: 300). Takšna oznaka se sicer večkrat pojavi v slovenskem tisku v Argentini (npr. Debeljak 1976b: 2; Meddobje 2009: 225; Svobodna Slovenija 7. 10. 2010: 1), pa tudi pri avtorjih, ki so te vire povzemali (npr. Peris 2014: 21).

1 Več o njeni izobrazbi glej Mislej 1998; 2007; Rijavec 2000; Peris 2014; Mizerit 2018. Avtorji, ki so opisovali življenje Branislave Sušnik, so se opirali predvsem na njena pričevanja in uradne predstavitve, ki pa so bila biografsko skopa in nepopolna. Debeljak je napisal, da o sebi ni želela govoriti in da je na vprašanja o njenem življenju dobival nejasne podatke (Debeljak 1976a: 299). 
Zakaj naj bi bil prav njen oče kot poveljnik žandarmerijske postaje v Devici Mariji v Polju prva žrtev revolucije, je Debeljak takole pojasnil:

[Ta] vas [je bila] leglo slovenskega komunizma, kajti tam je živel tik pred drugo vojno Edvard Kardelj, ki se je tam oženil z domačinko Pepco Mačkovo in kjer so se shajali tudi drugi vodilni komunisti iz ljubljanske okolice. Ko so začeli komunisti svojo revolucijo, je razumljivo z njihovega stališča, da so najprej »likvidirali« vodje prav te žandarmerijske postaje, ki je največ vedela o voditeljih revolucije. (Debeljak 1976a: 299)

Ti opisi kažejo, da travmatično izgubo očeta med drugo svetovno vojno, begunsko izkušnjo po vojni in migracijo $v$ Argentino slovenski tisk v Argentini interpretira skozi odnos do komunizma in nasprotovanje avtoritarnim režimom. Nikjer ne omenjajo, da so njenega očeta ubili zaradi njegovih dobrih povezav $z$ italijansko okupacijsko vojsko. Branislava Sušnik je tudi sama večkrat trdila, da sta bili prav vojna in komunistična revolucija v Jugoslaviji razlog za njeno izselitev iz domovine (glej Debeljak 1976a; prim. Peris 2014: 21-23). Pozneje je omenjala še, da je bila zaprta v komunistični ječi, kar se nanaša na čas, ko je bila zaradi poskusa bega v Italijo zaprta v Ajdovščini. Po vrnitvi v Ljubljano ji je uspelo zbežati v Avstrijo in nato $v$ Rim. $V$ Rimu se je povezala s frančiškanskim redom šolskih sester (Peris 2014: 24), pa tudi z Miho Krekom, nekdanjim ministrom $v$ jugoslovanski vladi, ki je do emigracije $v$ ZDA leta 1947 vodil Narodni odbor za Slovenijo.

$S$ pomočjo frančiškanskega reda šolskih sester in poznanstev $v$ Rimu je pridobila dovoljenje za emigracijo v Argentino, kamor se je po letu 1947 napotila množica drugih slovenskih povojnih političnih beguncev, ki so na možnost emigracije čakali po begunskih taboriščih v Italiji in Avstriji (glej Žigon 2001; Repič 2006). Nekateri begunci so bili med vojno pripadniki domobranske vojske, mnogi pa so kot civilisti zbežali iz strahu pred komunizmom; med drugo svetovno vojno so se bolj ali manj aktivno postavili na stran domobrancev in nasprotnikov »komunistične revolucije«. Bali so se represije, maščevanja ali nadlegovanja zaradi nasprotovanja komunizmu (glej Švent 1995). Po migraciji v Argentino so, tudi zaradi skupne begunske izkušnje, oblikovali tesno povezano skupnost $\mathrm{s}$ šolami, z lokalnimi kulturnimi domovi, bogatim tiskom in s kulturno dejavnostjo (Rot 1994; Švent 1994; Repič 2017). Branislava Sušnik je v Buenos Aires prispela 27. aprila 1947. V Argentini se je sprva povezala s Filozofsko fakulteto Univerze v Buenos Airesu in z Etnografskim muzejem Univerze v La Plati, a je zavrnila povabilo profesorja Joséja Imbellonija k poklicnemu sodelovanju z muzejem (Mislej 2007: 573; Peris 2014: 32).

V obdobju po migraciji je bila Branislava Sušnik delno vpeta tudi v novo nastajajočo slovensko skupnost v Buenos Airesu, ${ }^{2}$ a jo je ideološki okvir skupnosti, ki se je

$2 \quad$ V Argentini je že obstajala relativno velika slovenska skupnost, ki so jo sestavljali večinoma slovenski migranti po prvi svetovni vojni (glej Molek 2019). Politično pa so bili novi slovenski priseljenci zaradi medvojne kolaboracije z nacizmom in nasprotovanja komunističnemu režimu na povsem drugi ideološki strani. Med obema skupnostma dolgo praktično ni bilo stikov. 
zapirala vase, se upirala integraciji in se oblikovala v prepričanju po skorajšnji vrnitvi v domovino, tudi omejevala. Zanimala so jo staroselska ljudstva Južne Amerike in nova dežela, v kateri se je naselila, iskala pa je tudi možnosti za intelektualni razvoj. Najprej se je preizkusila v misijonarskem delu, ki jo je približalo staroselcem. S slovenskimi šolskimi sestrami, ki so v Argentini delovale od leta 1931, se je podala v misijon Laishi Formosa v pokrajini Čako na meji med Argentino in Paragvajem. Tam je živela med ljudstvom Toba in opravila tudi prve terenske etnografske raziskave (Mizerit 2018: 40).

Red šolskih sester je deloval v Asunciónu v Paragvaju, kjer je Branislava Sušnik spoznala zdravnika Andrésa Barbera, premožnega filantropa in mecena znanosti. Barbero je že leta 1929 ustanovil etnografski muzej, ki ga je do smrti leta 1950 vodil nemški etnolog in amerikanist Max Schmidt. Na povabilo Barbere se je Branislava Sušnik 10. marca 1951 preselila v Paragvaj in prevzela vodenje Etnografskega muzeja Andrés Barbero v Asunciónu v Paragvaju. Odmaknila se je od avtokratskih režimov, sprva komunističnega režima $v$ Jugoslaviji in nato peronističnega v Argentini (Peris 2014: 23). V Paragvaj je prišla $v$ času anarhije kot posledice preteklih vojn in avtokratskih režimov. Maja 1954 je Alfred Stroessner v Paragvaju izvedel državni udar in uvedel vojaško diktaturo, ki se je obdržala vse do njegovega izgnanstva leta 1989. Kljub zavračanju avtokratskih režimov se Branislava Sušnik ni več selila. Ostala je v Paragvaju in delala kot raziskovalka, muzeologinja in predavateljica na Nacionalni univerzi v Asunciónu. Paragvajsko državljanstvo je pridobila leta 1956, direktorica muzeja pa ostala vse do smrti 29. aprila 1996. V Slovenijo se ni nikoli vrnila.

Branislava Sušnik je šele po migraciji v Paragvaj našla osebno in znanstveno svobodo (Mislej 1993; 1998; Saksida 2012: 35), čeprav jo je v Južno Ameriko, kot je to povzel Tine Debeljak, pripeljala begunska usoda. »Tam je po začetnih težavah slednjega imigranta, ki je moral najprej živeti, začela iz zasebne volje prodirati v indijanske jezikovne in etnografske posebnosti« (Debeljak 1976a: 300).

Paragvaj je bil za Branislavo Sušnik nova domovina in »družbenokulturni laboratorij«, nato je vse življenje posvetila preučevanju paragvajskih staroselskih ljudstev, njihovih jezikov, mitologij, miselnih svetov, verskih predstav, materialne kulture in zgodovine kolonializma (Peris 2014: 21). »Moje strokovno zanimanje je res veljalo študiju azijskih jezikov, toda vojna me je vrgla na ameriška tla, kjer še odmeva zvok kakih 240 različnih indijanskih jezikov. [...] V Paragvaju živi še 13 različnih plemen - lepa okoliščina za etnološka raziskovanja.« (Sušnik, v Debeljak 1958: 320)

Uveljavljanje $v$ znanosti in novi domovini zanjo ni bilo enostavno, saj je bila priseljenka in se je morala kot ženska uveljaviti v moškem akademskem svetu. V pogovoru z Debeljakom je poudarila tri glavne dejavnike, ki so ji omogočili znanstveno uveljavitev. Prvo je bilo njeno nastopno predavanje $v$ paragvajskem Ateneu leta 1953, v katerem je predavala o staroselski mitologiji, mitoloških izročilih in njihovem delovanju oziroma »moči življenja« (Debeljak 1976a: 300). Prislužila si je veliko navdušenja in odobravanja, ki sta ji v Paragvaju odprla vrata v institucionalni svet znanosti. „Poslušalci so vse tako dobro srazumelis, da so me hitro klasificirali kot sbicho raror 
(redka živalca), in ta novi `doktorski titek je bila prva >garancija za mojo znanstveno ssposobnost«" (Sušnik, v Debeljak 1958: 320; prim. Telban 1993).

Drugi temelj akademske avtoritete je bila zavezanost terenskemu raziskovalnemu delu. Že s prvim petmesečnim bivanjem med staroselci Lengua in poznavanjem njihovega jezika je pridobila občudovanje pretežno moške znanstvene srenje. Večmesečnim terenskim odpravam je ostala zavezana tudi pozneje. Opravila je devetnajst raziskovalnih odprav, ki so večinoma trajale med pet in osem mesecev (glej Rijavec 2000: 49). Odprave je pogosto opravljala tudi pod okriljem vojske oziroma z njeno finančno pomočjo. »V prvih letih (1951-1952) [so ji] res privatne ustanove omogočile znanstveno raziskovanje indijanskega jezika in življenja, šele nato pa najprej - ministrstvo vojske« (Debeljak 1976a: 300). S Stroessnerjevim avtokratskim režimom je živela v nekakšnem sožitju, a se je držala stran od politike in ostajala izključno v znanosti. Terensko raziskovalno delo ji je uspevalo tudi zaradi talenta za jezike. Poleg razumevanja več evropskih jezikov naj bi aktivno obvladala osem jezikov paragvajskih staroselcev, vseh skupaj naj bi jih razumela kar devetnajst (Saksida 2012: 36). O njenem daru za jezike se je spletlo prepričanje, da se je španščine naučila kar na ladji med plovbo čez Atlantik (Peris 2014: 23).

Tretji temelj uveljavitve je pridobila s profesuro in predavanji na Filozofski fakulteti Nacionalne univerze v Asunciónu. Na univerzi je leta 1953 prvič predavala na temo Zgodovina ognja in vode med ameriškimi plemeni (Debeljak 1958: 320). Sprva je predavala le en semester, po letu 1960 pa je začela redno predavati o paragvajski etnografiji in arheologiji ter antropoloških in jezikoslovnih značilnostih staroselskih skupnosti. Dve desetletji je ob delu v muzeju poučevala tudi na Filozofski fakulteti Nacionalne univerze v Asunciónu, kjer je vodila katedro za južnoameriško arheologijo in antropologijo (glej Mislej 1998: 279).

Slovela je kot težka osebnost, ekscentrična raziskovalka, bila je tudi zelo nedostopna (Peris 2014: 15). Sama je to vsaj delno pripisovala težkim življenjskim izkušnjam in migraciji. »Da sem kljub brezbrižnosti in - včasih - sovražnosti paragvajskega okolja, vzdržala, mi je gotovo pomagal meni prikrojen upor vsemu, kar je ımoraš in ıne smeš« (Sušnik, v Debeljak 1958: 320).

V Paragvaju se je uveljavila kot raziskovalka, sprva v stroki, pozneje tudi v javnem življenju. Kljub težkim izkušnjam begunstva in migracije $v$ Paragvaj je tam našla raziskovalno avtonomijo in znanstveno svobodo, ki sta jo izpolnjevali in ji ju ni uspelo doseči v domovini ali Argentini. »Ko sem trpela v Ajdovščini v komunistični ječi, [...] pač nisem niti sanjala o tej svoji novi življenjski poti, katero ljubim in katera je vredna vsake osebne odpovedi in žrtve« (Sušnik, v Debeljak 1976a: 303).

Kot avtorica množice knjig in člankov o staroselskih ljudstvih, njihovih jezikih in kulturnih značilnostih je postala ena vodilnih paragvajskih znanstvenic $v$ antropologiji, etnolingvistiki, arheologiji in kulturni zgodovini (glej Peris 2014; Pusineri 2015). Leta 1993 je prejela predsednikovo nacionalno nagrado za dosežke $v$ znanosti, po smrti pa še predsednikovo odlikovanje za znanstveni prispevek k paragvajski identiteti (glej Mislej 1998: 279; Rijavec 2000: 29-30; Mizerit 2018: 39-41). 


\section{PODOBE BRANISLAVE SUŠNIK MED SLOVENCI V ARGENTINI}

Mirko Vasle je Branislavo Sušnik v knjigi o slovenskih znanstvenikih umestil v poglavje Slovenski znanstveniki v Argentini (Vasle 2013: 277-278). S povojno slovensko emigracijo je res delila begunsko izkušnjo, a se je od nje kmalu odmaknila. Stike je ohranjala le $z$ redkimi posamezniki in se občasno pojavljala v slovenskem tisku v Argentini, sprva z znanstvenimi članki, pozneje pa so objavljali intervjuje z njo, krajša poročila o dosežkih ali daljše opise njenega življenja in dela med staroselci (npr. Debeljak 1958; 1976a; Mizerit 2018).

Za poznavanje Branislave Sušnik je bil v slovenski povojni diaspori najzaslužnejši Tine Debeljak, ki je z njo leta 1958 naredil poglobljen intervju in ga, skupaj s svojim opisom njenega življenja, objavil v reviji Meddobje (Debeljak 1958). Pozneje je Debeljak z njo večkrat komuniciral osebno ali po pismih. Članek o Branislavi Sušnik je ponovno objavil leta 1976 v Zborniku Svobodne Slovenije (Debeljak 1976a), dodal pa mu je seznam njenih do tedaj objavljenih znanstvenih del. Drugi avtorji (npr. Mizerit 2009 ; 2018) so zbrane Debeljakove podatke predvsem prevzemali. Tako so se oblikovale podobe o »izseljenski znanstvenici«. Povezovali so jo tudi z drugimi raziskovalci ameriških staroselskih ljudstev, zlasti s Friderikom Barago in z Janezom Benigarjem. Debeljak je $v$ uvodni predstavitvi članka z naslovom Srečanje z raziskovalko indijanskih plemen dr. Branko Sušnikovo napisal:

Takoj mi je šinilo skozi spomin: saj to je prava naslednica našega Barage in Knobleharja (ne v smislu misijonarjenja, temveč v smislu znanstvenega, etnografskega in jezikovnega raziskovanja primitivnih poganskih plemen): tradicija Barage, ki je pisal slovarje in slovnice, in tradicija Knobleharja, ki je v znanstvenih društvih Evrope govoril o svojih nilskih raziskovanjih. Segel sem še bliže: ali ni direktna nadaljevateljica Slovenca Ivana Benigarja, ki je pred leti (1950) umrl v Argentini kmalu po našem prihodu sem, in je bil poliglot, jezikoslovec, in celo tako tesno povezan z indijanskimi plemeni, da si je svojo družico izbral iz njih in se naselil za stalno med njimi. (Debeljak 1958: 319)

Podobe o delu Branislave Sušnik med staroselci so se opirale na katoliškega škofa in misijonarja Friderika Barago, ki je v prvi polovici 19. stoletja živel v Kanadi in deloval med severnoameriškimi ljudstvi Očipve in Otava ter opisoval njihov jezik, slovnico in navade (Šmitek 1986). Baraga ima posebno spominsko mesto v slovenski diaspori v Argentini: po njem so poimenovali več ustanov, npr. Baragovo misijonišče ob slovenski cerkvi Marije kraljice in Slovensko ljudsko šolo Friderika I. Barage, oboje v Slovenski vasi v Lanúsu, predmestju Buenos Airesa. ${ }^{3}$

3 Tudi Misijon Svetega Cirila in Metoda, versko središče Slovencev v Kewu v Melbournu, Avstralija, se imenuje Baragova hiša. Prav tako se po Frideriku Baragi imenuje ena od slovenskih skupnosti v Kanadi, Slovensko Baragovo društvo v Quebecu. 
Tudi Branislava Sušnik je sprva odšla v misijon, med ljudstvo Toba, pozneje pa je raziskovala večja staroselska ljudstva Paragvaja, med drugim ljudstva Lengua, Čamakokov, Gvaranijev in druge. »Po stopinjah Barage je Branislava Sušnik v latinskoameriških deželah nadaljevala njegovo tradicijo, na svojih odpravah pisala slovnice in sestavljala slovarje, vedno s pošteno in prijazno obravnavo preučevanih ljudstev« (Peris 2014: 20).

Zaradi zanimanja za staroselska ljudstva jo je Debeljak primerjal tudi z etnologom in jezikoslovcem Janezom Benigarjem, ki se je v Argentino preselil leta 1908 in odšel v takrat še odročne kraje argentinske notranjosti, sprva v provinco Río Negro in nato v Neuquén. Med Mapuči se je naselil, oženil in si ustvaril družino ter pisal o njihovem jeziku in konceptih prostora in časa. (Benigar 1924; 1925)

Kakor je njeno delo svojevrstno, je vendar le nadaljevanje že 150 let stare slovenske tradicije, kot jo poznamo $v$ delu škofa Barage med severnoameriškimi Indijanci, dr. Knobleharja v področju nilskih črncev, pa zopet patagonskega "gaucha, oz. caciqueja« Ivana Benigarja. Vsi ti poligloti so študirali in prvi zapisovali primitivne jezike, pa tudi njihove etnografske značilnosti in posebnosti. (Debeljak 1976a: 303)

Kot izseljensko znanstvenico je Debeljak Branislavo Sušnik primerjal tudi z etnologom Rajkom Ložarjem, ki je prav tako po drugi svetovni vojni iz političnih razlogov zapustil domovino in odšel v Združene države Amerike (glej Slavec Gradišnik 2005). Začetek pogovora z Branislavo Sušnik je takole zapisal: »[s]te že druga znanstvenica iz slovenske emigracije, ki zavzema tako mesto. Ko bi bil tukaj še dr. Ložar, ki je nekaj let ravnatelj muzeja v Manitowocu (ZDA), bi vajino kramljanje bilo še posebno zanimivo«. (Debeljak 1958: 319; prim. Debeljak 1976a: 303)

Rajko Ložar je bil direktor Slovenskega etnografskega muzeja v Ljubljani med letoma 1940 in 1945, nakar je iz političnih razlogov emigriral v ZDA, kjer je od leta 1956 do upokojitve leta 1969 upravljal Mestni muzej v Manitowocu. Branislava Sušnik pa je prevzela vodenje etnografskega muzeja v Asunciónu, čeprav pred tem z muzeji ni imela izkušenj. Predvsem pa je Debeljak pri obeh prepoznal podoben strokovni interes.

Zaradi zanimanja za staroselce jo je Debeljak povezoval tudi s svojo svakinjo, slikarko Baro Remec, ki so jo - kot umetnico - prav tako zanimala ameriška staroselska ljudstva. Bara Remec je bila ena od redkih oseb v slovenski diaspori, s katero je Branislava Sušnik ohranjala bližnje prijateljstvo in redne stike.

In končno lahko ob teh primerjavah omenjamo tudi delo argentinske slikarke Bare Remec, ki tudi že dve desetletji redno obiskuje Indijance $v$ Bariločah na jugu Argentine kakor tudi v Tilkari na severu, kjer kot amaterka išče ostanke starih indijanskih predmetov, kot umetnica pa z intuitivno vživljenostjo oblikuje njih pokrajino, njih življenje in njih mitologijo. [...] Tako sta se dve slovenski ženi-emigrantki srečali kot 
znanstvenica in umetnica na istem ustvarjalnem področju v tesnem stiku z južnoameriškimi indijanskimi plemeni. (Debeljak 1976a: 303)

Pri oblikovanju podob o njej kot »raziskovalki indijanskih plemen« (Debeljak 1958) so bili pomembni tudi njene strokovne objave v slovenskem tisku v Argentini in občasni obiski Buenos Airesa, med katerimi je predavala pri Slovenski kulturni akciji. Znanstvena besedila v slovenskem jeziku je Branislava Sušnik objavljala izključno v Buenos Airesu, in še to le v zgodnjem obdobju (Sušnik 1953; 1954a; 1954b; 1959; 2018). Ti članki so sicer le manjši del njenega bogatega znanstvenega opusa, ki obsega več kot 77 objav (Mislej 1998: 277; Peris 2014: 11; prim. Terčelj, Pusineri 2007).

$\checkmark$ zgodnjem raziskovalnem obdobju v petdesetih in šestdesetih letih 20. stoletja se je Branislava Sušnik posvečala etnolingvističnim in antropološkim raziskavam jezikov, mitoloških tradicij in sodobnega življenja staroselskih ljudstev Toba, Lengua, Mak'á, Čamakoko, Gvaraní in Aché Guajakí. Od poznih šestdesetih let se je posvečala predvsem kulturni zgodovini paragvajskih staroselskih ljudstev, njihovim kolonialnim stikom, migracijskim premikom zaradi kolonialnih pritiskov in religioznim, družbenim ter kulturnim spremembam (Saksida 2012: 43-44; Peris 2014: 30).

Vsa dela, izdana pri slovenski skupnosti v Argentini, segajo v petdeseta leta 20. stoletja in spadajo med zgodnje antropološke in jezikoslovne raziskave med staroselskimi ljudstvi v Paragvaju. V dveh člankih obravnava jezik in religiozne prakse skupine Lengua (Sušnik 1953; 1954b), v enem pa totemizem in šamanizem pri Čamakokih (Sušnik 1959). Članek Primitivec kot človek (Sušnik 2018) je nastal po predavanju leta 1959 v okviru dogodkov Slovenske kulturne akcije. ${ }^{4}$ Temeljno znanstveno vprašanje v zgodnjih delih je bilo, kaj pomeni biti človek (Mislej 1998). Odgovor je iskala v jezikih, mitologijah in animističnih praksah. Animizem (in totemizem) je obravnavala kot strukturo družbe, pravil in razmerij, prehajanja med individualnim in kolektivnim ter kot način, kako so v skupnem okolju medsebojno vzpostavljena človeška in nečloveška bitja. »lzmed 230 južnoameriških plemen več kot dve tretjini plemen same sebe imenuje ımi/ljudjeı, ena tretjina pa drugim odreka pravi človeški ımi«« (Sušnik 2018: 55).

Na prošnjo Ladislava Lenčka je v reviji Katoliški misijoni objavila članek o misijonarski situaciji in možnostih za misijone med staroselci v Paragvaju (Sušnik 1954a). V besedilu je povzela glavne značilnosti delovanja misijonov med različnimi paragvajskimi ljudstvi, tudi v odvisnosti od njihove integracije v kolonialni sistem. Izrazito pa je bila kritična do protestantskih misijonarskih praks. Opozarjala je na stereotipe in pokroviteljski odnos misijonarjev, etnologov in drugih, ki prihajajo v stik s staroselci. Opozorila je tudi na odgovornost države v odnosu do staroselskih ljudstev, saj je »indijansko vprašanje [...] socialno vprašanje države same« (Sušnik 1954a: 14). Članek izraža naklonjenost katoliškemu misijonarskemu delu med staroselci, pa tudi zelo

4 Tone Mizerit je opisal, kako je skoraj šestdeset let po predavanju po naključju našel njen neobjavljeni članek: »Kakšno je bilo moje presenečenje, ko sem kot avtorja neobjavljenega članka zagledal ime: Branka Sušnik» (Mizerit 2018: 38). 
odklonilen odnos do vsega, kar spominja na komunizem: »Med temi Indijanci sproletarci<, ki se tako smilijo socialističnim `debeluharjemı, ni več poglavarjev niti čarovnikov [...] V pristaniščih se udejstvujejo salezijanci, naravno je, da je njihova prva skrb namenjena belcem, a še ti se kažejo precej odporni pod vplivom raznih delavskih sizmov'." (Sušnik 1954a: 16)

Druge omembe Branislave Sušnik v slovenskem tisku v Argentini so občasne in priložnostne, npr. ob izdaji njenih knjig (Debeljak 1976b; 1983), ob podelitvi paragvajskega državnega priznanja, post festum pa ob izdaji poštne znamke z njeno podobo v Paragavju leta 2005 (Svobodna Slovenija 17. 11. 2005: 4) in ob poimenovanju ulice po njej. Objave pogosto izražajo ponos nad dosežki Slovencev v izseljenstvu:

Kam vse smo ponesli slovensko ime in sadove slovenske krvi! [...] Tudi v Argentini bi jih lahko mnogo našteli, začenši z etnologom Janezom Benigarjem in arhitektom Sulčičem. In še filozof Milan Komar, umetnostni zgodovinar Darko Šušteršič, glaciolog Peter Skvarča, etnologinja Branka Sušnik v Paragvaju. [...] Za nove domovine so to Amerikanci, Kanadčani, Avstralci, Argentinci; za nas so in ostanejo Slovenci. (Mizerit 2009: 99)

Takšni zapisi pa pogosto izražajo tudi frustracijo, da izseljenci v domovini niso cenjeni ali so celo zamolčani (Mizerit 2018: 42). V novici o poimenovanju ulice po Branislavi Sušnik v Asunciónu je tudi kritičen zapis: »O poimenovanju ulice v Paragvaju so obširno poročali mediji po vsej Sloveniji. A (skoraj razumljivo) nobeden ni omenil, da je Branka tja prišla kot begunka, še manj, da je bil njen oče, kot vodja žandarmerijske postaje v Devici Mariji v Polju, prva žrtev revolucije v Sloveniji.« (Svobodna Slovenija 7. 1. 2010: 1)

\section{"ZAMOLČANOST« ALI NEPOZNAVANJE BRANISLAVE SUŠNIK V SLOVENIJI}

Debeljak je že zgodaj trdil, da javnost in stroka $v$ domovini ne poznata znanstvenih del Branislave Sušnik. »Gotovo je dr. Branka Sušnik med slovenskimi ženami v svetu - in v emigraciji po I. 1945 še posebej - dosegla najvišje znanstveno priznanje za svoje delo, pa je gotovo najmanj znana svojim slovenskim rojakom v svetu« (Debeljak 1976a: 299).

Zapis ob smrti Branislave Sušnik leta 1996 v reviji Misli, ki izhaja v Avstraliji, prav tako ocenjuje, da je bila raziskovalka zaradi begunstva in iz političnih razlogov zamolčana tudi v znanosti: »Dr. Branka Sušnik si je s svojimi znanstvenimi ekspedicijami, predavanji ter publikacijami pridobila svetovni ugled. Rojaki smo samo zunaj domovine vedeli zanjo, dočim je Slovenija pod enoumjem o njej žal molčala. Pa zasluži topel spomin vsaj zdaj po smrti.« (Misli/Thoughts 45/1996: 218) 
V Sloveniji Branislava Sušnik res ni bila znana, a trditev, da je bila povsem zamolčana, tudi ne drži. Eno prvih objav o njej najdemo pri Niku Kuretu, ki jo je poznal že iz gimnazijskih let. Ko je delal na Inštitutu za slovensko narodopisje, je z njo ohranjal občasne stike tudi na strokovnih področjih. Leta 1974 je v Traditionesu zapisal kratko, a zelo pozitivno oceno dveh njenih knjig o Čamakokih (Sušnik 1969; 1970). Med drugim je zapisal: »Branislava Sušnik pri nas še ni znano ime. [...] Spodobi se, da poznamo delo svoje rojakinje Branke Sušnikove, čeprav deluje med tujim ethnosom na tuji celini.« (Kuret 1974: 252)

Tudi Mizerit je zapisal, da jo je slovenska javnost spoznala šele po osamosvojitvi, prej je bila, tako kot mnogi drugi begunci oziroma izseljenci, "zamolčana« (Mizerit 2018: 39). Zamolčanost Branislave Sušnik zaradi političnega konteksta njene emigracije in vpetosti $v$ slovensko diasporo $v$ Argentini ni bil edini razlog za slabo poznavanje njenega dela. Drugi razlog je gotovo ta, da je bila večina njenih del objavljena $\checkmark$ španskem jeziku in dolgo zelo slabo dostopna. Nekaj del je poslala v Slovenijo, ni se pa prav zares trudila ohranjati stike $z$ domovino (Mizerit 2018: 39). Zato lahko trditev o zamolčanosti razumemo tudi v ideološkem okviru diaspore, a so jo povzeli nekateri slovenski avtorji. Ralf Čeplak Mencin je po njeni smrti povzel razlog za njeno zamolčanost. »Dr. Branislava Sušnik je sodila v skupino t. i. zamolčanih izseljenskih znanstvenikov oziroma znanstvenic, čeprav se sama ni nikoli politično kompromitirala. Ožigosalo jo je že to, da se je po drugi svetovni vojni izselila iz Slovenije.« (Čeplak Mencin 1997: 461)

Slovenski znanstveni in laični javnosti jo je najprej približala Irene Mislej (1993; 1997; 2007), pozneje je srečanje z njo na kratko opisal tudi Blaž Telban (1993). Po njeni smrti so o njej pisali še Ralf Čeplak Mencin (1997), Maja Rijavec (2000), Aleksandra Saksida (2012) in drugi. Njeno življenje je bilo predstavljeno na več razstavah (npr. leta 2010 v NUK-u), RTV Slovenija pa je v režiji Matjaža Žbontarja leta 2010 posnela film z naslovom Šamanka Branka. Leta 2020 so ob stoletnici njenega rojstva pripravili več dogodkov, npr. odkritje plakete in razstave v Medvodah. Tako se Branislava Sušnik simbolno vrača $v$ domovino. Okoli njenega življenja se sočasno $z$ oblikovanjem spomina nanjo spleta tudi precej nove mitologije s predznakom heroizma ženske raziskovalke. Analize njenih znanstvenih del so za zdaj še redke (Saksida 2012).

$\checkmark$ domovino se ni nikoli vrnila, stiki pa so bili le omejeni in redki. Dopisovala si je predvsem z mamo in s sestro, tudi o domotožju, odrekanju, osamljenosti in trdem življenju v Paragvaju (glej Geršak 2020). Ob občasnih stikih s Slovenci v Argentini pa je govorila tudi o svojem odnosu do domovine. "Slovenka sem se rodila in po slovensko čutim; Slovenija je moja rodna in čustvena domovina! Istočasno pa spoštujem in sem hvaležna Paragvaju kot danes svoji adoptivni domovini.« (Sušnik, v Debeljak 1976a: 303)

Živela je skromno, nikoli se ni poročila ali imela otrok. V Paragvaju je bivala kar v manjši sobi v muzeju in tam 28. aprila 1996 tudi umrla. 
Ko so nekega jutra vstopili v njeno sobico, je bila dr. Sušnikova že nekaj ur mrtva v svoji postelji. Na nočni omarici pa je ležala antologija slovenske poezije v španskem prevodu, ki ji jo je ob obisku podaril Marko Jensterle. Odprta je bila na strani, kjer je bila natisnjena pesem EXILIO (Eksil - Pregnanstvo) pesnika Borisa A. Novaka. (Mizerit 2018: 39)

Tudi njeni sodelavci so povedali, da se je predvsem zadnja leta večkrat z domotožjem spominjala Slovenije (Peris 2014: 43-44; Pusineri 2015). Peris je zapisal, da se je z »velikim hrepenenjem in bolečino [...] spominjala svoje domovine, svojega kraja na svetu s čudovitimi gorami, toplim vetrom in pomirjujočimi vodami« (Peris 2014: 14). Branislavo Sušnik je vse življenje, ki ga je posvečala raziskovalnemu delu, spremljala tudi begunska izkušnja. Pustila ji je neizbrisne osebne travme, obenem pa ji omogočila, da je novo domovino in poslanstvo našla v znanosti.

\section{ZAKLJUČEK}

Prispevek o Branislavi Sušnik obravnava migracijske razsežnosti njenega življenja, po drugi svetovni vojni predvsem begunstvo kot dejavnik oblikovanja življenjske poti in političnih ideoloških stališč, uveljavitev v Paragvaju kot njeni novi domovini in vpetost $v$ slovensko diasporo v Argentini, oziroma podobe, ki so se oblikovale o njej in njenem raziskovalnem delu. Prav migracija, v katero sta jo prisilili politična situacija v domovini in osebna travma zaradi nasilne izgube očeta med vojno, jo je privedla do novega življenja v Paragvaju, kjer je našla osebno in znanstveno svobodo, uspelo pa se ji je tudi uveljaviti v dominantno moškem akademskem svetu.

Prispevek se osredotoča predvsem na povezave Branislave Sušnik s slovensko skupnostjo v Argentini ter oblikovanje podob o njej kot »izseljenski znanstvenici« in »raziskovalki indijanskih plemen«. Prispevki v slovenskem tisku so jo povezovali z drugimi znanimi misijonarji in raziskovalci, predvsem pa jo je prisvojila slovenska diaspora. Podobe o njej so tesno povezane $z$ ideološkim okvirom slovenske diaspore v Argentini, predvsem v protikomunistični ideološki drži in interpretacijah razlogov za begunstvo. Te podobe in diasporični interpretativni okvir so vplivali tudi na druge avtorje, ki so podatke o Branislavi Sušnik povzemali iz slovenskega tiska v Argentini. Poleg tega je dobro poznavanje Branislave Sušnik med Slovenci v Argentini v nasprotju s slabim poznavanjem njenega dela $v$ domovini vse do devetdesetih let 20. stoletja. Razlog je bil v splošni zamolčanosti izseljenskih znanstvenikov, umetnikov in kulturnikov, pa tudi v oddaljenosti raziskovalnih tematik. V Slovenijo se ni nikoli vrnila, je pa ohranjala intimno vez z domovino, zlasti zadnja leta je iz njenih zasebnih zapisov in pogovorov s sodelavci razvidno domotožje. Vse do danes Branislava Sušnik ostaja pomemben del razvoja antropologije v Paragvaju in Južni Ameriki, prispevki o njej, ki so se začeli pojavljati v devetdesetih letih 20. stoletja tudi v slovenskem strokovnem tisku, pa njeno delo počasi približujejo tudi slovenski javnosti. 


\section{LITERATURA}

Benigar, Juan (1924). El concepto del tiempo entre los araucanos. Boletín de la Junta de Historia y Numismática Americana 1, 137-154.

Benigar, Juan (1925). El concepto de espacio entre los araucanos. Boletín de la Junta de Historia y Numismática Americana 2, 67-83.

Čeplak Mencin, Ralf (1997). In memoriam: Dr. Branislava Sušnik 1920-1996. Etnolog 7, 461-463.

Debeljak, Tine (1958). Srečanje z raziskovalko indijanskih plemen dr. Branko Sušnikovo. Meddobje 4/4, 319-324 (ponatis 2018 v: Meddobje / Entresiglos 52/1-4, 43-50).

Debeljak, Tine (1976a). Dr. Branislava Sušnik: Raziskovalka indijanskih plemen. Zbornik Svobodne Slovenije 1973-1975: V tridesetem letu našega zdomstva, 1945-1975 (ur. Miloš Stare). Buenos Aires: Svobodna Slovenija, 299-305.

Debeljak, Tine (1976b). Med knjigami in revijami. Zbornik Svobodne Slovenije 19731975. Svobodna Slovenija = Eslovenia libre 29/46, 2.

Debeljak, Tine (1983). Tri knjige dr. Branislave Sušnik: Med knjigami in revijami. Svobodna Slovenija = Eslovenia libre 42/40, 2.

Geršak, Urša (2020). Skica nekih razmišljanj = Bosquejo de unos pensamientos. Bivališča Branislave Sušnik: 31 zgodb (ur. Barbara Pregelj). Ljubljana: Malinc.

Kuret, Niko (1974). Branislava Sušnik, Chamacocos, I. Cambio cultural. Museo Etnografico »Andrés Barbero«, Asunción (Paraguay) 1969, 246 str., in Branislava Sušnik, Chamacocos, II. Diccionario etnografico, Museo Etnografico »Andrés Barbero«, Asunción (Paraguay) 1970, 202 str. Ocena knjig. Traditiones 3, 252.

Mislej, Irene (1993). Dr. Branislava Sušnik, slovenska antropologinja v Paragvaju: Nedokončana zgodba. Slovenski koledar: Koledar za Slovence po svetu 40, 266-271.

Mislej, Irene (1998). Dr. Branislava Sušnik (1920-1996): Slovenska znanstvenica v tropskem Paragvaju. Traditiones 27, 275-281.

Mislej, Irene (2007). Branislava Sušnik (1920-1996): Antropologinja, raziskovalka južnoameriških Indijancev, dobitnica najpomembnejših paragvajskih priznanj za znanstveno delo. Pozabljena polovica: Portreti žensk 19. in 20. stoletja na Slovenskem (ur. Alenka Šelih, Milica Antić Gaber, Alenka Puhar, Tanja Rener, Rapa Šuklje, Marta Verginella). Ljubljana: Tuma, SAZU, 572-576.

Mizerit, Tone (2009). (Pre)živeti v dveh svetovih. Vabljeno uvodno predavanje na 9. vseslovenskem srečanju v prostorih Državnega zbora Republike Slovenije, 2. julij 2009. Meddobje / Entresiglos 43/1-4, 93-99.

Mizerit, Tone (2018). Branka Sušnik. Meddobje / Entresiglos 52/1-4, 38-42.

Molek, Nadia (2019). Biti Slovenec v Argentini: Kompleksnost identitetnih procesov argentinskih Slovencev. Ljubljana: Založba ZRC.

Peris, Carlos (2014). Branislava Susnik: La antropóloga del Paraguay. Asunción: El Lector. Pusineri, Adelina (2015). Dra. Branislava Susnik: Vida y obra. Pensamiento crítico en el Paraguay: Memoria del Ciclo del Conversatorios. Asunción: BASE-IS, 127-158, http://www.portalguarani.com/965_branislava_susnik/30930_dra_branislava_ 
susnik_vida_y_obra__por_adelina_pusineripensamiento_critico_en_el_paraguay__ano_2015.html (15. 7. 2020).

Repič, Jaka (2006). »Po sledovih korenin«: Transnacionalne migracije med Argentino in

Evropo. Ljubljana: Oddelek za etnologijo in kulturno antropologijo Filozofske fakultete Univerze v Ljubljani.

Repič, Jaka (2017). The Impact of Mobilities on Visual Arts in the Slovenian Diaspora in Argentina. Dve domovini / Two Homelands 46, 7-22.

Rijavec, Maja (2000). Dr. Branislava Sušnik - Slovenska znanstvenica v Paragvaju. Diplomska naloga. Ljubljana: Oddelek za etnologijo in kulturno antropologijo Filozofske fakultete Univerze $v$ Ljubljani.

Rot, Andrej (1994). Republika duhov: Štiridesetletnica Slovenske kulturne akcije. Ljubljana: Državna založba Slovenije.

Saksida, Aleksandra (2012). Antropologija Branislave Sušnik. Monitor 14/2, 33-69.

Slavec Gradišnik, Ingrid (ur.) (2005). Pretrgane korenine: Sledi življenja in dela Rajka Ložarja. Ljubljana: ZRC SAZU.

Sušnik, Branislava (1953). Med Indijanci Lengua. Misijonski zbornik (ur. Ladislav Lenček). Buenos Aires: Katoliški misijoni (Slovenska misijonska zveza), 143-152.

Sušnik, Branislava (1954a). Pogoji za misijone v Paraguaju. Katoliški misijoni (Buenos Aires), marec, april, maj, junij.

Sušnik, Branislava (1954b). Verovanje indijancev Lengua. Vrednote / Los Valores. Buenos Aires: Slovenska kulturna akcija, 169-177.

Sušnik, Branislava (1959). Totemizem in šamanizem pri Čamakokih. Zgodovinski zbornik (ur. Marijan Marolt). Buenos Aires: Slovenska kulturna akcija, 198-209.

Sušnik, Branislava (1969). Chamacocos, I. Cambio cultural. Asunción: Museo Etnografico Andrés Barbero.

Sušnik, Branislava (1970). Chamacocos, II. Diccionario etnografico. Asunción: Museo Etnografico Andrés Barbero.

Sušnik, Branislava (2018). Primitivec kot človek: Predavanje dr. Branke Sušnik na 15. Kulturnem večeru Slovenske kulturne akcije, 10. novembra 1959. Meddobje / Entresiglos 52/1-4, 51-61.

Šmitek, Zmago (1986). Klic daljnih svetov: Slovenci in neevropske kulture. Ljubljana: Borec. Švent, Rozina (1994). Štiridesetletnica delovanja SKA. Dve domovini / Two Homelands $5,179-182$.

Švent, Rozina (1995). Begunski usodi naproti. Dve domovini / Two Homelands 6, 43-51. Telban, Blaž (1993). »Bicho Raro« paragvajskih ravnic ali srečanje z dr. Branislavo Sušnik. Etnolog 3, 205-214.

Terčelj, Marija Mojca, Pusineri, Adelina (2007). Dra. Branislava Sušnik y su contribución a la antropología paraguaya: Expectativa y desafío para futuras relaciones científicas entre Eslovenia y Paraguay. Europa Balcánica y los países de la cuenca del Mar negro - MERCOSUR: Procesos de transición, concertación e integración y sus impactos sobre la cooperación económica, política y cultural (ur. Slobodan S. Pajović). Beograd: Univerza Megatrend, CEISAL, 339-348. 
Vasle, Mirko (2013). Científicos eslovenos a través del tiempo. Buenos Aires: Editorial Baraga del Centro Misional Baraga.

Žigon, Zvone (2001). Iz spomina $v$ prihodnost: Slovenska politična emigracija v Argentini. Ljubljana: ZRC SAZU. 


\section{SUMMARY}

\section{IMAGES OF BRANISLAVA SUŠNIK AMONG THE SLOVENIANS IN ARGENTINA: MIGRATION, LIFE IN PARAGUAY, AND CONNECTIONS WITH THE HOMELAND \\ Jaka REPIC}

The article presents the life and research of Branislava Sušnik, who fled from Slovenia after World War II, emigrating first to Argentina and eventually to Paraguay. In Paraguay, she worked in ethnolinguistics, anthropology, and the cultural history of the indigenous peoples of Paraguay. The article mainly analyzes her experiences of migration, her connections with the homeland, and especially the images of Branislava Sušnik as a migrant scientist constructed in the publications of the Slovenian diaspora in Argentina.

Branislava Sušnik was a distinguished researcher dedicated to studying the indigenous groups of Paraguay, their languages, their cultural and cosmological characteristics, and the socio-cultural changes in colonial history. She was educated in Ljubljana, Vienna, and Rome but chose exile after World War II. She emigrated to Argentina, where she was vaguely involved in the emerging Slovenian diaspora. However, as she sought personal and scientific freedom, she did not like the autocratic Peronist regime, and the diaspora was also too introverted and homeland oriented. After spending a year in the mission in Chaco, she moved to Paraguay. In Paraguay, she became a researcher, the director of the Ethnographic Museum Andrés Barbero, and a professor at the National University in Asunción. The paper provides an analysis of the multiple layers of Branislava Sušnik's migration experiences, her connections with the homeland and with Slovenians in Argentina. Although she distanced herself from the Slovenian diaspora in Argentina, she sporadically maintained ties with certain individuals there.

She was also considered one of the most-respected Slovenian emigrant scientists. The article examines the images that the Slovenian publications in Argentina constructed of her, especially in connection with the personal and socio-political reasons for migration and the anti-communist position. These images not only helped to establish an interpretative model for understanding her life and work in Paraguay but also to facilitate the symbolic return of the memories of Branislava Sušnik to Slovenia. 